\title{
THE CORELATION BETWEEN LANGUAGE LEARNING STRATEGIES AND STUDENTS THINKING STYLE OF ELEVENTH GRADE OF SMA NEGERI 4 BAUBAU
}

\author{
La Ode Supardi, Baharudin \& Yunita Sari
}

Dosen Program Studi Pendidikan Bahasa Inggris FKIP Unidayan Baubau

\begin{abstract}
ABSTRAK
Tujuan utama penelitian ini adalah menyelidiki hubungan strategi belajar siswa dengan gaya berpikir siswa kelas dua SMA Negeri 4 Baubau. Instrumen penelitian menggunakan angket-angket strategi belajar siswa diadopsi dari angket yang dikembangkan oleh Rebecca Oxford (1999) and angket gaya berpikir siswa diadopsi dari Sternberg \& Wagner (1992). Data penelitian dianalisis secara statistik. Statistik deskriptif untuk mendesripsikan hasil penelitian dan statistik inferensial dengan Pearson Product Moment untuk menguji hipotesis penelitian. Hasil penelitian menunjukkan bahwa ada hubungan yang signifikan antara strategi belajar siswa dan gaya berpikir siswa yang dibuktikan oleh nilai sig $=0,014<0,05$ dengan nilai koefisien korelasi $r=0,387$.
\end{abstract}

Kata kunci: Strategi belajar siswa, gaya berpikir siswa

\section{INTRODUCTION}

Language teaching can work well if there is sufficient knowledge of the characteristics and behavior of learners. In a process of teaching and learning, there are always successful learners and less successful learners. This is due to various factors; one of which is the way the student learns. In this case, all forms of language teaching can be well developed if we have sufficient knowledge about the learners and about the learning process itself. Thus, knowledge of the characteristics of learners will be helpful in facilitating teaching and learning activities so that learners can achieve maximum results. In answer to the problems in the learning process, a proper learning strategy is required. This strategy will be a golden eye in achieving the learning process.

Claire Weinstein and Ricard Meyer (1986), stated that "good teaching involves teaching students how to learn, how to remember, how to think, and how to motivate themselves." The two figures argue that teaching students how to learn is a major educational goal. In addition, many teachers are less able to carry out the opinions of Weinstein and Meyer. Often students are taught about school subject matter without any guidance on how to learn effectively and efficiently from teachers. Or, at least the teachers can give students time to think about the essence of the lesson students are studying. We expect students to solve problems but rarely teach them about problem solving. And, similarly, we sometimes ask students to remember a large amount of teaching material but seldom teach them the art of memorization. Now it's time for us to fix our weaknesses, it's time we developed the science of applied learning and problem solving and memory. We need to develop the general principles of how to learn, how to remember, how to 
solve problems, and then to package them in the form of ready-to-apply lessons, and then incorporate these methods into the curriculum. "

The above arguments contain insight and provide strong arguments for the importance of learning strategies. A language learning strategy is a way in which learners gain, store, experiment, and utilize the information they get (Oxford, 1990). It also added that learning strategy is an activity that can make learning process easier, faster, more fun, more focused, more effective, and easier to use in new situations (Oxford, 1990:8). Language learning strategy is all tactics, policies, or plans to achieve the goals of language learning (Suardi Saparani, et al, 1997:22).

Strategy lessons are grounded in the proposition that student success, largely dependent on the skills to learn independently and monitor their own learning. This makes learning strategies absolutely taught to students individually, ranging from low-grade, primary school, and continuing through high school and college. Students should learn about the various strategies that exist and how to use them properly.

In the process of learning there are various characteristics of students in learning as well as with the thinking style of the students of learning style of learners can be related to the variables of thinking styles. The term thinking styles is defined as one's habitual patterns or preferred ways of thinking while doing something (Sternberg, 1997). Thinking styles concerns the question of how one thinks that is different from how well one thinks.

Each learner has their own characteristics. None of them have the same in common as in thinking and learning. This diversity is one of the most important aspects for the teachers to be aware of. To stimulate the thinking activities of learners, it is necessary to know what they know and how they think.

In many cases, the teachers ignore the problem of these differences so that in the process there are learners whose learning needs are not met. Moreover, there is often a tendency for the teachers to expect the learners to follow their thinking style.

Thinking style is the way one chooses to use his abilities (Sternberg, 1997 in Santrock, 2004). While Taylor et al (1977:55) defines thinking as inferring process. Thinking is a process of drawing conclusions from a comprehensible problem that is then able to find solutions to the problem so as to produce new conclusions and findings. Of course, the conclusions in this thinking process are influenced by the engineering and manipulation of the data and/or understandings stored in a person's long term memory.

The neglect of this diversity and style of thinking has a considerable impact. Can we imagine what kind of learning situations experienced by learners whose style of thinking is not understood by teachers. So it is very important for the teachers to recognize the style of thinking and diversity of learners.

In studying English, there are some students thinking about the purpose of learning English itself, Some students assume that learning English is not important because they think they will not use it because they will not go abroad., this student's thinking style that makes it lazy to learn English. Usually when learning English we learn about the structure that discusses grammar, when learning grammar, many students do not like it, and they prefer it if the teacher directly gives examples of sentences commonly used in 
everyday life, regardless grammar form. There are still many teachers who do not know the style of thinking of each student and teachers is still less attention to the characteristics of each student and also the process of choosing language learning strategies.

From the above explanation a teachers should be required in recognizing the characteristics of each student, especially the characteristics of students' thinking styles, in addition teachers must also be prosecuted in choosing a language learning strategy that will be used when giving lessons.

Based on the background, the researchers formulate the problem statement as follow: is there any correlation between language learning strategies and students thinking style?

\section{RESEARCH METHOD}

\section{The Research Design}

The design of the research was a correlation design (non-experimental). Correlation was a reciprocal between the two variables. The design of the correlation of language learning strategies (X) and students thinking style (Y) was displayed in the following figure :

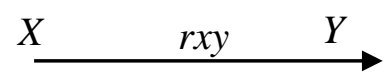

$\mathrm{X}$ : Language learning strategies

$\mathrm{Y}$ : Students thinking style

Ryx: Correlation between language learning strategies and students thinking style

\section{Population and Sample of the Research}

The population of this research is all the students of class XI SMAN 4 Baubau. They were class, XI IPA 1-12 counted 264 and XI IPS 1-12 counted 264. The sample of the researcher took two classes consist 40 students. The technique sampling in this research is cluster random sampling.

\section{The Instrument of the Research}

In this research, the researchers used questionnaires as instrument to collect the data. The questionnaire of language learning strategies the researchers adopted from
Oxford's LLS (1990), The alpha coefficient for reliability of the SILL is 0.92 (Griffiths, 2007) and content validity is 0.99 (Oxford \& Burry-Stock, 1995). where there are 50 Questions that is written in English and also translated into Indonesia to give easier the students to understand and answer the question. Each statement contains of the language learning strategies. This questionnaire has six types of strategies, involving Memory strategies, Cognitive strategies, Compensation strategies, Metacognitive strategies, Affective strategies and Social strategies,

Questionnaire for students thinking style, the researchers adopted from The Thinking Styles Inventory (Sternberg \& Wagner, 1992), The alpha co-efficient for reliability and validity of the TSI is 0.63 and 0,94 , so it can be said that inventory is quite reliable (Cortina, 1993 ) there are 65 question in the questionnaire. This questionnaire has five types, involving Function (Legislative, Executive, Judical), Forms ( Hierarchic, Oligarchic, Monarchic and anarchic), Level (Global and Local), Scope ( Internal and External), Learning (Liberal and Conservative).

Likert scale was applied for the questionnaire with consist of five optional answers, those are Never, Sometimes, Often, Usually, Always. 


\section{Techniques of Data Analysis}

In analyzing the data, the score of language learning strategies and students thinking style observed by the students was categorized using the following formula:

$$
p=\frac{\text { range }}{\text { number of classes }}
$$

(Sudjana, $2005: 74$ )

Based on the formula above, the score of language learning strategies and students thinking style were categorized as follow :

\section{The category of language learning strategies}

\begin{tabular}{ccl}
\hline No. & Score & Category \\
\hline 1. & $210-250$ & Very high \\
2. & $170-209$ & High \\
3. & $130-169$ & Enough \\
4. & $90-129$ & Low \\
5. & $50-89$ & Very low \\
\hline
\end{tabular}

The category of Students thinking style

\begin{tabular}{ccl}
\hline No. & Score & Category \\
\hline 1. & $273-325$ & Very high \\
2. & $221-272$ & High \\
3. & $169-220$ & Enough \\
4. & $117-168$ & Low \\
5. & $65-116$ & Very low \\
\hline
\end{tabular}

To find out the correlation between language learning strategies and students thinking style the kind of analysis used SPSS version 21 software was correlation analysis with determining the value of significance $(\alpha)=0.05$.

The criteria of receiving or rejecting the hypothesis are as follows :

1. If the probability value (sig. (2-tailed)) $>0,05$, the alternative hypothesis $\left(\mathrm{H}_{\mathrm{a}}\right)$ was rejected. It means there was not any significant correlation between language learning strategies and students thinking style.

2. If the probability value (sig. (2 tailed) $<0,05$, the alternative hypothesis $\left(\mathrm{H}_{\mathrm{a}}\right)$ was accepted. It means there was a significant correlation between language learning strategies and students thinking style.

To determine coefficient correlation, the researchers used the criteria in the following table.

\begin{tabular}{lcl}
\hline No. & $\begin{array}{c}\text { The Number of } \\
\text { Product Moment }\end{array}$ & Classification \\
\hline 1. & $0.0-0.20$ & very low \\
2. & $0.20-0.40$ & Low \\
3. & $0.40-0.70$ & Moderate \\
4. & $0.70-0.90$ & High \\
5. & $0.90-100$ & very high \\
\hline
\end{tabular}

\section{FINDING AND DISCUSSIONS}

\section{A. Finding}

To analyze the data about the language learning strategies and students thinking style, the researchers used a table frequency distribution. The table frequency distribution means here is to describe the distribution characteristics and the score of each variable (language learning strategies and students thinking style). The summary of descriptive statistic can be seen in the following table. 
Summary of Statistic Descriptive

\begin{tabular}{lcc}
\hline Statistic & $\begin{array}{c}\text { Language } \\
\text { Learning Strategy }\end{array}$ & $\begin{array}{c}\text { Students } \\
\text { Thinking Style }\end{array}$ \\
\hline Mean & 128,68 & 183,93 \\
Median & 126,00 & 185,00 \\
SD & 29,696 & 28,390 \\
Min Score & 76 & 107 \\
Max Score & 203 & 230 \\
\hline
\end{tabular}

1. The Questionnaire Result of Students' Language Learning Strategies

The result of the data analysis from 40 respondents at eleventh grade of SMAN 4 Baubau concerning about language learning strategies indicated that the highest score of language learning strategies is 203 and the lowest score of language learning strategies is 76128.68. The median of language learning strategies is 126 . The descriptive Statistic analysis showed that the mean of language learning strategies is 128.68 and Standard deviation of language learning strategies is 29.696. The detail of frequency distribution can be seen in the following table:

\begin{tabular}{cccl}
\hline $\begin{array}{c}\text { Score } \\
\text { Interval }\end{array}$ & Frequency & Percentage & Category \\
\hline $50-89$ & 3 & $7,5 \%$ & Very Low \\
$90-129$ & 20 & $50,0 \%$ & Low \\
$130-169$ & 15 & $37,5 \%$ & Moderate \\
$170-209$ & 2 & $5,0 \%$ & High \\
$210-250$ & 0 & $0 \%$ & Very High \\
\hline Total & $\mathbf{4 0}$ & $\mathbf{1 0 0 \%}$ & \\
\hline
\end{tabular}

Based on the table distribution score of language learning strategies there were $3(7.5 \%)$ students chose very low category, there were $20(50,0 \%)$ students chose low category, there were $15(37,5 \%)$ students chose moderate category, there were $2(5,0)$ students chose high category, and there was none $(0 \%)$ of students chose very high category. Therefore, it could be concluded that the language learning strategies of the students was in low category because most of students got low score.

\section{The Questionnaire Result of Students' Thinking style}

The result of the data analysis from 40 respondents at eleventh grade of SMAN 4 Baubau concerning about language learning strategies indicated that the highest score of language learning strategies is 230 and the lowest score of language learning strategies is 107. The median of language learning strategies is 185 . The descriptive Statistic analysis showed that the mean of language learning strategies is 183.93 and Standard deviation of language learning strategies is 28.39. The detail of frequency distribution can be seen in the following table:

\begin{tabular}{cccl}
\hline $\begin{array}{c}\text { Score } \\
\text { Interval }\end{array}$ & Frequency & Percentage & Category \\
\hline $65-116$ & 1 & $2,5 \%$ & Very Low \\
$117-168$ & 9 & $22,5 \%$ & Low \\
$169-220$ & 28 & $70,0 \%$ & Moderate \\
$221-272$ & 2 & $5,0 \%$ & High \\
$273-325$ & 0 & $0 \%$ & Very High \\
\hline Total & $\mathbf{4 0}$ & $\mathbf{1 0 0 \%}$ & \\
\hline
\end{tabular}


Based on the table distribution score of students thinking style there were $1(2,5 \%)$ students chose very low category, there were $9(22,5 \%)$ students chose low category, there were 28 (70,0\%) students chose moderate category, there were $2(5,0)$ students chose high category, and there was 0 $(0 \%)$ students chose very high category. Therefore, it could be concluded that the thinking style of the students was in moderate category because most of students got moderate score.

\section{Hypothesis Testing}

The correlation between language learning strategies (x) and students' thinking style (y) analyzed using Pearson Product Moment analysis. The strength of the correlation between language learning strategies $(\mathrm{x})$ and students' thinking style was indicated by the coefficient of Pearson Product Moment. The researchers used SPSS Version 21, and the result of analysis as shown by the output of the test below:

\section{Correlations}

\begin{tabular}{|rl|r|r|}
\hline & X & Y \\
\hline \multirow{4}{*}{ X } & Pearson Correlation & 1 & $.387^{*}$ \\
& Sig. (2-tailed) & & .014 \\
& N & 40 & 40 \\
& Pearson Correlation & $.387^{*}$ & 1 \\
Y Sig. (2-tailed) & .014 & 40 \\
\hline
\end{tabular}

*. Correlation is significant at the 0.05 level (2-tailed).

Based on the table above, it obtained that the coefficient correlation between language learning strategies (X) and students' thinking style (Y) was $r=0,387$, it was indicated that the correlation between language learning strategies (X) and students' thinking style (Y) the correlation was categorized in low correlation and significant value $\operatorname{sig}=0,014<(\alpha) 0,05$. Therefore, it could be concluded that there was a significant correlation between language learning strategies and students thinking style.

\section{B. Discussion}

The mean of language learning strategies is 128,68 . The median of language learning strategies is 126,00. Standard deviation of language learning strategies is 26,696. Maximal score of language learning strategies is 203 and minimum score of language learning strategies is 76 . Based on the mean score, it could be concluded that the language learning strategies was in low category.

Then, the descriptive Statistic analysis, the mean of students thinking style is 183,93 . The median of students thinking style is 185,00 . Standard deviation of language learning strategies is 28,390 . Maximal score of language learning strategies is 230 and minimum score of language learning strategies is 170 . Based on the mean score, it could be concluded that the language learning strategies was in moderate category.

The result of testing hypothesis the proposed research hypothesis was accepted. The result of testing the hypothesis was there was a significant correlation between language learning strategies and students thinking style. The value of the correlation 
coefficient (rxy) between language learning strategies and students thinking style $\mathrm{r}=$ 0,387 with the category low correlation and significant value sig $=0,014<\alpha=0,05$ it was indicated that there was a significant correlation between language learning strategies and students thinking style.

This research learned support research done by Khodae Balestane, M.,
Hashemnezhad, H., \& Javidi, that showed there was a significant correlation between language learning strategies and students thinking style. The value of the correlation coefficient (rxy) between language learning strategies and students thinking style with the number of correlation $=0,176$ with the category low correlation.

\section{CONCLUSION}

The result of testing hypothesis the proposed research hypothesis was accepted. The result of testing the hypothesis there was a significant correlation between language learning strategies and students thinking style. The value of the correlation coefficient (rxy) between language learning strategies and students thinking style $\mathrm{r}=$ 0,387 with the category low correlation and value of sig $=0,014<0,05$ it was indicated that there is a significant correlation between language learning strategies and students thinking style.

\section{REFERENCES}

Bochenski, dalam Suriasumantri (ed), 1983:52. From: http//www psikologi pendidikan.com//html.

Cohen, A. D. 1998. Strategies in learning and using a second language. London: Longman.

Djamiah Husain. 2011. Fostering Autonomous Learning Inside and Outside The Classroom in Language Learning. Makassar. UNM Publisher.

Hamruni. 2012. Strategi Pembelajaran. Yogyakarta: Insan Madani.

Khodae Balestane, M., Hashemnezhad, H., \& Javidi, Sh. 2012. The Relationship between Language Learning Strategies and Thinking Styles of Iranian EFL Learners. International Journal of Research Studies in Language Learning. Volume 2 Number 4, 3-19.
Mojgan, F and Alireza, H. 2016. Relationship between Thinking Styles and Academic Achievement of the Students. INTERNATIONAL JOURNAL OF HUMANITIES AND CULTURAL STUDIES ISSN 2356-5926.

O'Malley, and Chamot. 1990. Learning Strategies in Second Language Acquisition. New York: Cambridge University Press.

Oxford, R. L. 1990. Language Learning Strategies: What Every Teacher Should Know. Boston: Heinle \& Heinle.

Oxford, R. L., \& Burry-Stock, J. A. 1995. Assessing the Use of Language Learning Strategies Worldwide with the ESL/EFL version of the Strategy Inventory for Language Learning (SILL). System, 23(1), 1-23. 
Richard, J.C., and H. Platt. 1992. Longman Dictionary of Language Teaching and Applied Linguistics (New Ed). UK: Longman Group UK Ltd.

Rubin, J. 1997. What the Good Language Learner can Teach us. TESOL Quarterly 9, 1. 1975.

Sternberg, R. J. 1997. Thinking Styles. New York: Cambridge University Press.

Stren, H. 1992. Issues and Options in Language Teaching (edited posthumously by Patrick Allen \& Birgit Harley). Oxford: Oxford University Press.

Sugiyono, (2014). Metode Penelitian Kuantitatif Kualitatif dan $R \& D$. Bandung Alfabeta.

Wenden, A. \& Rubin J. (Eds). 1987. Learner Strategies in Language Learning. London: Prentice-Hall International Ltd. 